\title{
Hot Pressing of Boron Carbide Based Ceramic Composites
}

\author{
Pavol Švec, Zuzana Gábrišová, Alena Brusilová
}

Institute of Technologies and Materials, Faculty of Mechanical Engineering, Slovak University of Technology in Bratislava. Námestie slobody 17, 81231 Bratislava. Slovak Republic. E-mail: pavol.svec@stuba.sk, zuzana.gabrisova@stuba.sk, alena.brusilova@stuba.sk

Ceramic composite materials based on boron carbide were hot pressed utilising in situ reaction of boron carbide powder with $40 \mathrm{wt} . \%$ of titanium dioxide sintering additive. The samples were prepared at sintering temperature of $1850{ }^{\circ} \mathrm{C}$, pressure of $35 \mathrm{MPa}$, and time of $60 \mathrm{~min}$ in vacuum atmosphere of about 20 $\mathrm{Pa}$. Optimisation of sintering regime concentrating on both heating stage of sintering and application of pressure enabled to prepare fully dense ceramic composite materials composed of boron carbide matrix with 29.5 vol. $\%$ of titanium diboride secondary phase. The ceramic composite reached average density of $99.31 \%$, hardness of $29.8 \mathrm{GPa}$, and fracture toughness of $6.9 \mathrm{MPa} . \mathrm{m}^{1 / 2}$.

Keywords: boron carbide, ceramic composite, sintering, microstructure

\section{Introduction}

Boron carbide $\left(\mathrm{B}_{4} \mathrm{C}\right)$ based ceramics and ceramic composites with $\mathrm{B}_{4} \mathrm{C}$ matrix have been intensively studied materials because of their extraordinary properties that stem from their microstructure. Boron carbide is according its mainly covalent bonds extremely hard, corrosion resistant and wear resistant material at both room and elevated temperatures. Low density, high Young modulus and high absorption cross section for neutrons are other important properties of $\mathrm{B}_{4} \mathrm{C}$. One important advantage in comparison with many ceramic materials is good electric conductivity, which enables to form products from $\mathrm{B}_{4} \mathrm{C}$ by electrical discharge machining [1-4]. Based on its properties $\mathrm{B}_{4} \mathrm{C}$ ceramic and ceramic composites are promising material for production parts working in demanding working conditions. Extraordinary hardness predestines $\mathrm{B}_{4} \mathrm{C}$ for applications requiring high abrasive and erosive wear resistance such as sand-blast nozzles and water jet nozzles. Small density and high modulus of elasticity make $\mathrm{B}_{4} \mathrm{C}$ based ceramics a perspective material for light armour such as bullet-proof vests and aircraft applications. High active cross section of $\mathrm{B}_{4} \mathrm{C}$ for neutrons absorption can be utilised in nuclear technique [3-6].

The potential of $\mathrm{B}_{4} \mathrm{C}$ is decreased by both difficult sinterability and low fracture toughness of this ceramic material. Difficult sinterability of $\mathrm{B}_{4} \mathrm{C}$ stems from the low self-diffusion coefficients in this ceramic system. Relatively high temperatures, above $2300{ }^{\circ} \mathrm{C}$, are necessary to achieve compacts with the density near to the theoretical density of $2.52 \mathrm{~g} . \mathrm{cm}^{-3}$. However, the sintering of $\mathrm{B}_{4} \mathrm{C}$ ceramics at temperatures above $2000{ }^{\circ} \mathrm{C}$ is accompanied with particle coarsening in ceramic compacts which decrease mechanical properties such as strength, hardness and fracture toughness. However, the fracture toughness of $\mathrm{B}_{4} \mathrm{C}$ based ceramics must be improved for successful application of this ceramic material [3, 7-10].

Both problems of preparation of $\mathrm{B}_{4} \mathrm{C}$ based ceramics decreasing of sintering temperature and increasing of fracture toughness of samples can be solved by sintering of ceramic composite systems. Selection of suitable composite systems enables creation of new phases in situ during sintering process of $\mathrm{B}_{4} \mathrm{C}$ powder with proper sintering additives. Sintering additives improve densification and influence microstructure and mechanical properties of boron carbide based composite materials because of creation of secondary phases. The secondary phases are significant mainly for increasing of fracture toughness, which is critical for $\mathrm{B}_{4} \mathrm{C}$ based ceramic materials because it reaches values only from 2.2 to $3.7 \mathrm{MPa} \cdot \mathrm{m}^{1 / 2}$. Hardness of $\mathrm{B}_{4} \mathrm{C}$ based ceramic composite usually decreases, because phases with lower hardness create compared to $\mathrm{B}_{4} \mathrm{C}$. Using of fine-grained powders and application of pressure, which can be applied at hot pressing, during sintering process enables decreasing of sintering temperature too. [1, 4, 11-14].

Several metals (Al, Hf, Ti), non-metals (B, C) oxides $\left(\mathrm{Al}_{2} \mathrm{O}_{3}, \mathrm{HfO}_{2}, \mathrm{TiO}_{2}, \mathrm{ZrO}_{2}\right)$, and non-oxides $\left(\mathrm{Si}_{3} \mathrm{~N}_{4}, \mathrm{TiC}, \mathrm{W}_{2} \mathrm{~B}_{5}\right)$ are appropriate sintering additives for in situ sintering of $\mathrm{B}_{4} \mathrm{C}$ based ceramic composites $[8-10,12,13]$. At the sintering of $\mathrm{B}_{4} \mathrm{C}$ powder with titanium dioxide additive $\left(\mathrm{TiO}_{2}\right)$, the oxidic additive reacts with $\mathrm{B}_{4} \mathrm{C}$ and form the titanium diboride $\left(\mathrm{TiB}_{2}\right)$, which become a part of phase composition of created composite material. The process of in situ boride creation significantly enhances of $\mathrm{B}_{4} \mathrm{C}$ sinterability $[9,12$, 14-16]. From thermodynamic presumption stems that $\mathrm{B}_{4} \mathrm{C}$ - $\mathrm{TiB}_{2}$ ceramic composite material is created in 
consequence of in situ reaction between $\mathrm{B}_{4} \mathrm{C}$ and $\mathrm{TiO}_{2}$ initial powders, but the volatile species such as $\mathrm{CO}$ and $\mathrm{CO}_{2}$ are a part of in situ reaction, too. The final phase composition of sintered samples changes with portion of $\mathrm{TiO}_{2}$ in the initial powder mixture. The portion of volatile species grows with increased ratio of $\mathrm{TiO}_{2}$ in the initial $\mathrm{B}_{4} \mathrm{C}-\mathrm{TiO}_{2}$ powder mixture. Formation of volatile components complicates sample preparation. Increased care is necessary to give to their removing because removing of volatile species affect the densification of ceramic and so the rest-porosity of sintered samples $[4,8,10,17]$.

Microstructure and properties of $\mathrm{B}_{4} \mathrm{C}-\mathrm{TiB}_{2}$ ceramic composite materials depend mainly on volume portion of created phases, densification, and grain size. The proper densification of every ceramic composite with the relative density near full density is a necessary condition for advanced properties of ceramic samples. The fracture toughness of $\mathrm{B}_{4} \mathrm{C}-\mathrm{TiB}_{2}$ composite increases with portion of $\mathrm{TiB}_{2}$ phase in consequence of better fracture of $\mathrm{TiB}_{2}$ phase compared to $\mathrm{B}_{4} \mathrm{C}$ phase. The hardness decreases with portion of $\mathrm{TiB}_{2}$ phase because of lower hardness of $\mathrm{TiB}_{2}$ phase compared to $B_{4} C$ phase $[4,9,15,18]$.

Hot pressing process is one of preferred processes at the densification of $\mathrm{B}_{4} \mathrm{C}$ based ceramics, because simultaneous application of temperature and pressure enables significant decreasing of sintering temperature compared to pressureless sintering $[4,10,13,15,19]$. Proper outgassing of $\mathrm{B}_{4} \mathrm{C}$ based ceramic composite materials is important at hot pressing process with in situ reaction. Although hot pressing of $\mathrm{B}_{4} \mathrm{C}$ based ceramics has been studied in several works and essential information about the final sintering temperature have been published, the information about heating stage of sintering process and application of pressure is less presented. An optimal sintering regime is necessary for both proper removing of volatile species during sintering and preparation of dense compacts with enhanced properties and it was the aim of this study with concentration of heating stage of hot pressing.

\section{Used materials and evaluation methods}

Hot pressing process was chosen for fabrication of $\mathrm{B}_{4} \mathrm{C}-\mathrm{TiB}_{2}$ ceramic composite materials from $\mathrm{B}_{4} \mathrm{C}$ and $\mathrm{TiO}_{2}$ initial powders with the purity of $99 \%$ and a particle size from 2 to $3 \mu \mathrm{m}$. Initial powder mixture contained $40 \mathrm{wt} . \%$ of $\mathrm{TiO}_{2}$ sintering additive, because this composition was optimised in work [17]. The $\mathrm{B}_{4} \mathrm{C}$ and $\mathrm{TiO}_{2}$ initial powder mixture with $1 \mathrm{wt} . \%$ of binding wax was milled in Teflon container with $\mathrm{B}_{4} \mathrm{C}$ mill balls and isobutyl alcohol lubricant for 4 hours in the horizontal mill. After drying of initial powder mixture, precursors of cylindrical shape with a diameter of $12 \mathrm{~mm}$ were prepared by die pressing in simple steel tool with floating die. The precursors were consequently hot pressed in graphite die with floating matrix of cylindrical shape with a diameter of $12 \mathrm{~mm}$. Several hot pressing regimes with different heating stages of sintering processes were applied. However, the final process parameters such as sintering temperature of $1850{ }^{\circ} \mathrm{C}$, pressure of $35 \mathrm{MPa}$, sintering time of $60 \mathrm{~min}$ and a vacuum atmosphere about $20 \mathrm{~Pa}$ were the same for all regimes, because they allowed optimal combination of mechanical properties according the result in work [17].

The surfaces of bulk samples were observed using stereomicroscope Zeiss Technival 2. The densities of hot pressed samples were measured using Archimedes method. Theoretical density of $\mathrm{B}_{4} \mathrm{C}-\mathrm{TiB}_{2}\left(3.11 \mathrm{~g} \cdot \mathrm{cm}^{-3}\right)$ ceramic composite was calculated based on both theoretical densities of $\mathrm{B}_{4} \mathrm{C}\left(2.52\right.$ g.cm $\left.{ }^{-3}\right)$ and $\mathrm{TiB}_{2}(4.52$ g. $\left.\mathrm{cm}^{-3}\right)$ phases and their volume portions $(70.5 \mathrm{vol} \%$ $\mathrm{B}_{4} \mathrm{C} 29.5$ vol. $\% \mathrm{TiB}_{2}$ ) measured using the image analysis for samples hot pressed at optimal sintering regime. Relative densities of $\mathrm{B}_{4} \mathrm{C}-\mathrm{TiB}_{2}$ ceramic composites hot pressed at different sintering regimes were calculated by comparison of their densities with the theoretical density value of 3.11 g. $\mathrm{cm}^{-3}(100 \%)$. The microstructures were studied on cross sections of ceramic composite samples using light microscopy with Axiovert 40 MAT microscope and using electron microscopy with JEOL JSM-IT300 scanning electron microscope. The phase analysis was done using $\mathrm{X}$ ray diffraction method with Philips PW 1710 diffractometer. Volume portions of identified phases were measured using image analysis. The hardness and fracture toughness were measured by indentation method using Vickers indenter Buehler IndentaMet 1100.

\section{Results and discussion}

Sintering regime of boron carbide based ceramic composite material was optimised to enable removing of volatile species created by in situ reaction and microstructure formation during hot pressing of powder mixtures with the initial composition of $\mathrm{B}_{4} \mathrm{C}$ with 40 wt. $\% \mathrm{TiO}$ sintering additives. Although different sintering regimes were applied, the same final sintering temperature of $1850^{\circ} \mathrm{C}$, pressure of $35 \mathrm{MPa}$, time pressing time of $60 \mathrm{~min}$ in vacuum atmosphere about $20 \mathrm{~Pa}$ were applied for all composite samples.

\section{Optimization of sintering regime during hot pressing} of $\mathrm{B}_{4} \mathrm{C}$ based ceramic composites

The optimization of sintering regime was focused on both heating stage of sintering process and application of pressure considering in situ reaction. The optimal sintering regime should enable to remove the volatile species which accompanied in situ reaction and prepare the ceramic composites without the rest porosity. The in situ reaction kinetic during hot pressing of $\mathrm{B}_{4} \mathrm{C}$ and $\mathrm{TiO}_{2}$ initial powder mixtures was identified by measuring of vacuum level in chamber of hot 
press using vacuum gauge because the in situ reaction was accompanied by decrease of vacuum level. The W5Rh-W26Rh thermocouple was used for the measuring of sintering temperature. The densification progress during sintering of ceramic composite samples was observed according to motion of punch of die tool during hot pressing process and it allowed to calculate the densification speed in different sintering phases.

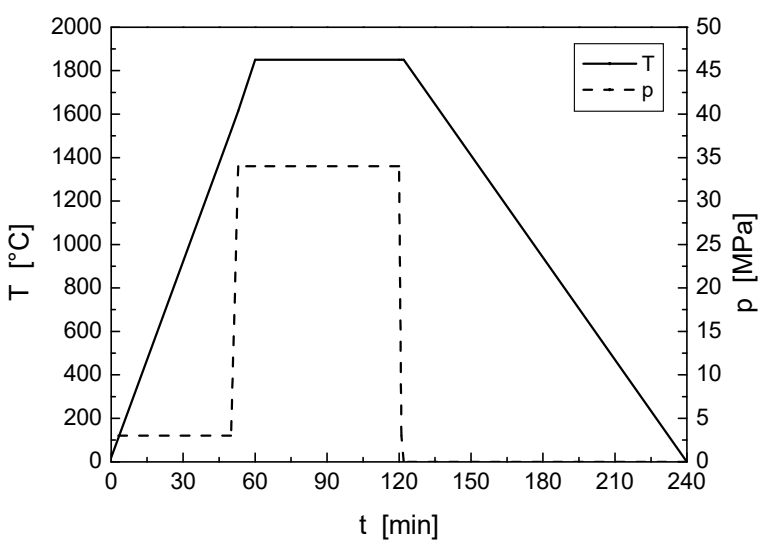

Fig. 1 Progress of sintering temperature $(T)$ and pressure $(p)$ during initial sintering regime

The initial sintering regime applied during the hot pressing of ceramic composite samples is demonstrated in fig. 1. Hot pressing in accordance with this initial sintering regime (fig. 1) was characterised by progressive application of sintering pressure after reaching the temperature of $1500{ }^{\circ} \mathrm{C}$. In this stage of hot pressing, the vacuum level rapidly decreased, which indicated intensive in situ reaction between $\mathrm{B}_{4} \mathrm{C}$ and $\mathrm{TiO}_{2}$ initial powder components. Progress of sintering temperature and vacuum level during hot pressing of $\mathrm{B}_{4} \mathrm{C}$ based ceramic composites is depicted in fig. 2. According to the vacuum level in fig. 2, volatile species significantly created in the temperature interval from 1500 to $1850{ }^{\circ} \mathrm{C}$. Creation of relative high portion of volatile species, probably $\mathrm{CO}$ and $\mathrm{CO}_{2}$, was confirmed by measuring of weight loss of hot pressed samples, which was about $30 \mathrm{wt} . \%$. The maximal sintering pressure of $35 \mathrm{MPa}$ was applied at the temperature about $1570{ }^{\circ} \mathrm{C}$. The densification speed reached the maximal value of $2.5 \mathrm{~mm} \cdot \mathrm{min}^{-1}$ shortly after application of full pressure of $35 \mathrm{MPa}$ at the temperature of $1570{ }^{\circ} \mathrm{C}$. Later, densification speed decreased and at the end of the dwell at the final sintering temperature of $1850{ }^{\circ} \mathrm{C}$ for $60 \mathrm{~min}$ it stabilised at the value of $0.01 \mathrm{~mm} . \mathrm{min}^{-1}$. At this stage of sintering process, the vacuum level in chamber of hot press chamber reached the minimal value about $20 \mathrm{~Pa}$.

It was not possible to obtain ceramic composite compacts without surface defects using the initial sintering regime during hot pressing of ceramic composite samples. Application of pressure at the beginning stage of in situ reaction at the temperature of $1570{ }^{\circ} \mathrm{C}$ caused creation of several cracks and large pores. These defects can be seen on the base of the cylindrical surface of $\mathrm{B}_{4} \mathrm{C}$ based ceramic composite compact in fig 3. It could be considered that the porosity of ceramic composite fulfilled the function of canals for removing of volatile species $\left(\mathrm{CO}\right.$ and $\mathrm{CO}_{2}$ ) created by in situ reaction during hot pressing process. The cracks were the consequence of premature application of pressure. The density values of these samples were $91.18 \pm 1.22 \%$ and are presented in fig. 6 . Several surface defects caused relatively large scattering of measured density values as can be seen in fig. 6. As these values are not enough for reaching of advanced mechanical properties of sintered ceramic composite compacts, mechanical properties of samples were not measured.

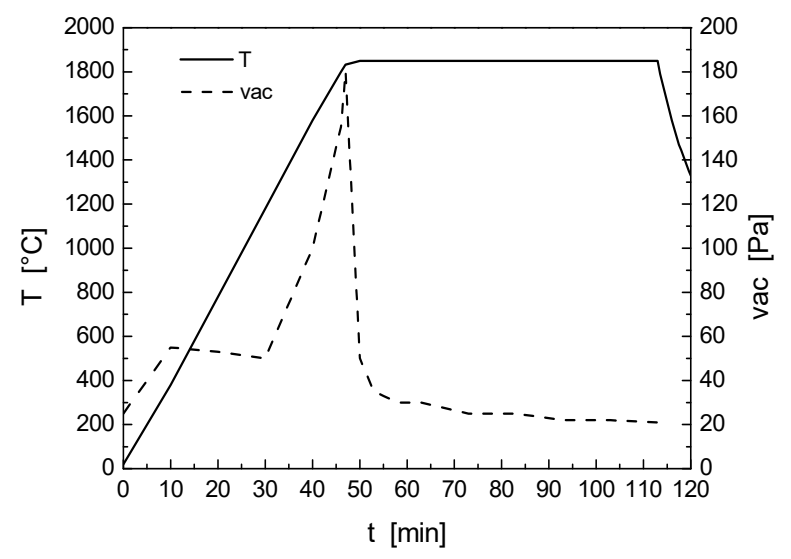

Fig. 2 Progress of sintering temperature $(T)$ and vacuum level (vac) during hot pressing of $B_{4} C$ based ceramic composites

Based on the results achieved during the hot pressing with the initial sintering regime in fig. 1, the heating stage of hot pressing process was several times modified. Significant progress in densification of hot pressed $\mathrm{B}_{4} \mathrm{C}$ based ceramic composite materials was achieved by adding of a dwell at the temperature of $1570{ }^{\circ} \mathrm{C}$ for time of $60 \mathrm{~min}$ during the heating stage of a modified sintering regime. The dwell was added to prolongate the stage during removal of created volatile species during the densification of sample when the material has still adequate open porosity. The modified sintering regime had a positive effect on decreasing of cracks on surface of samples, but the densification of samples was insufficient. The density reached the value of $96.24 \pm 0.32 \%$. When comparing the densities achieved at modified sintering regime with the initial regime (see fig. 6), significant increase of density with narrowed interval was achieved. However, the differences in the density values across the samples were observed on cross section of samples hot pressed with this modified sintering regime. Although the surfaces of samples were properly densified, the centres of samples proved relatively large 
amount of rest porosity. The rest porosity in the centres of samples was caused by premature densification of surface areas of samples, before the volatile species could be removed from the bulk volume.

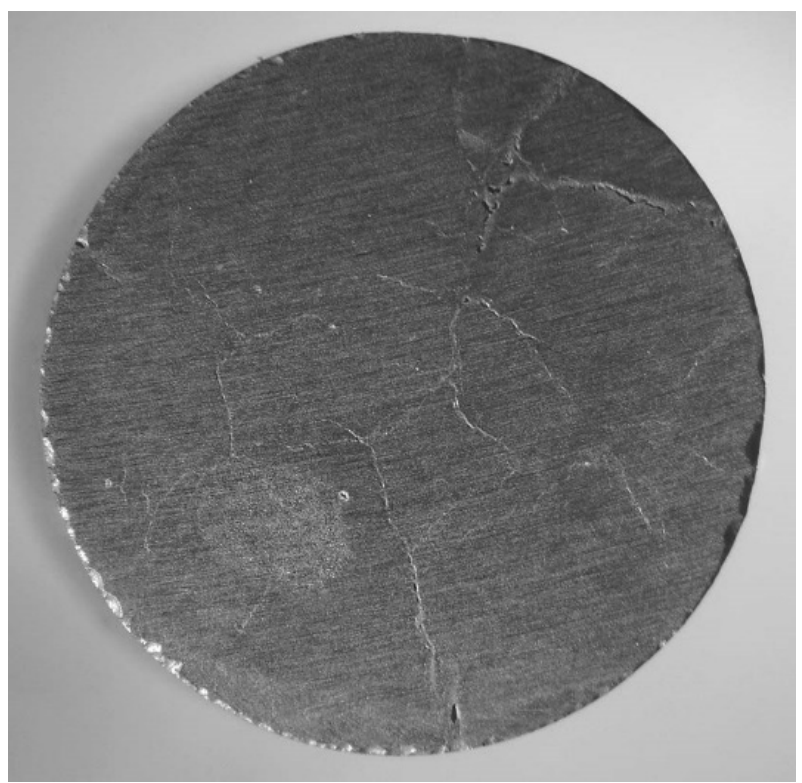

Fig. 3 Surface cracks and pores created in $B_{4} C$ based ceramic composite bot pressed using initial sintering regime

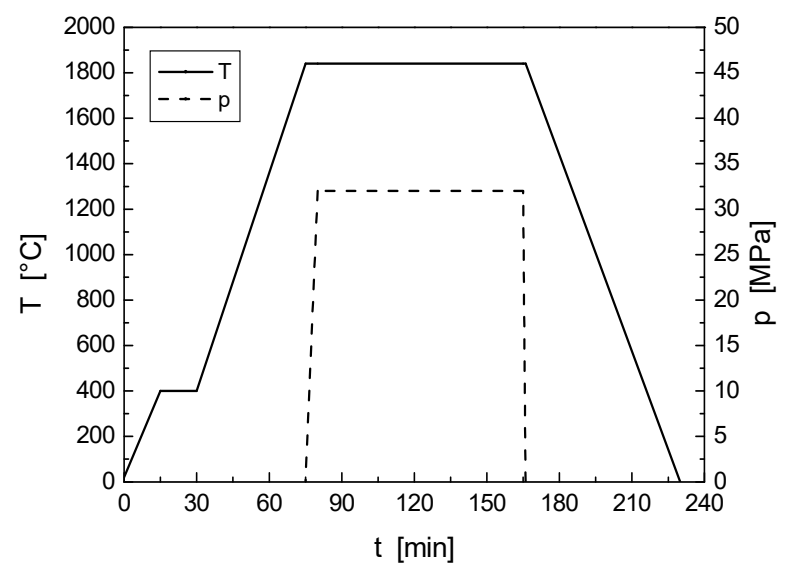

Fig. 4 Progress of sintering temperature $(T)$ and pressure ( $p)$ during optimal sintering regime

Based on the results achieved during hot pressing using several modified sintering regimes, it was found that the full sintering pressure should be applied at higher temperature compared to previous regimes. So, the hot pressing process was modified as can be seen in fig. 4 and this regime could be labelled as the optimal sintering regime. During the heating stage of the optimal sintering regime a dwell at the temperature of $400{ }^{\circ} \mathrm{C}$ for time of $15 \mathrm{~min}$ was added to improve the removing of binding wax added at cold pressing of precursors. Progressive application of pressure started only at the maximal sintering temperature of $1850{ }^{\circ} \mathrm{C}$. The optimal sintering regime allowed both the elimination of cracks and proper densification of ceramic composite samples with the density of $99.31 \pm 0.26$
$\%$. The densities achieved at the optimal sintering regime are compared with densities measured at initial and modified sintering regimes in fig. 6 . The average density at the optimal regime $(99.31 \%)$ increased significantly compared to modified regime $(96.24 \%)$, but variation of measured densities improved only slightly. Hot pressed bulk compacts were without any surface defects, as can be seen in fig. 5 , where the cylindrical ceramic composite sample with a diameter of $12 \mathrm{~mm}$ and a height of $12 \mathrm{~mm}$ is documented.

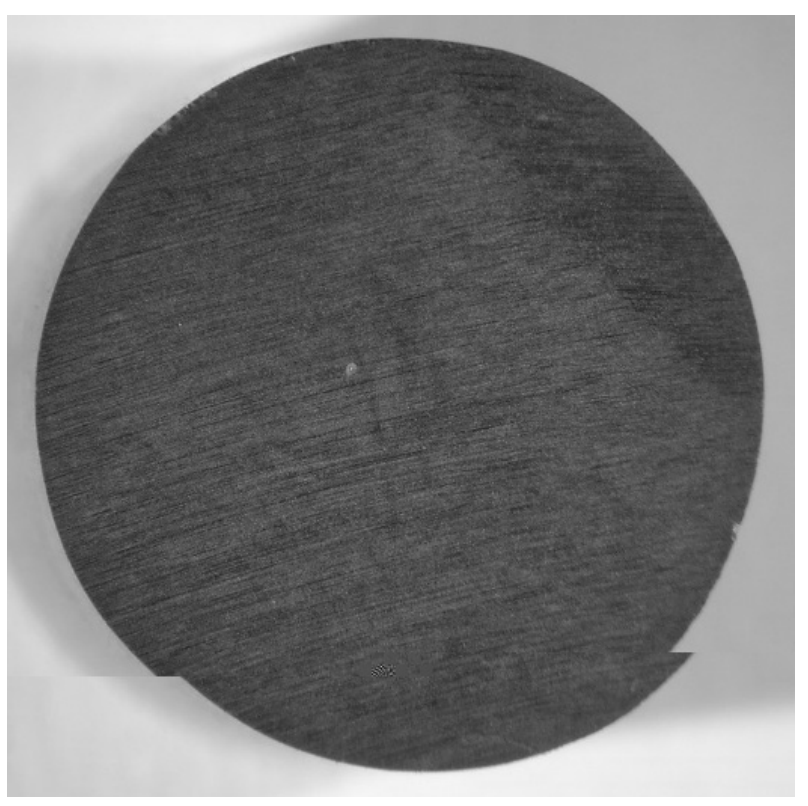

Fig. $5 \mathrm{~B}_{4} \mathrm{C}$ based ceramic composite without surface defects hot pressed using optimal sintering regime

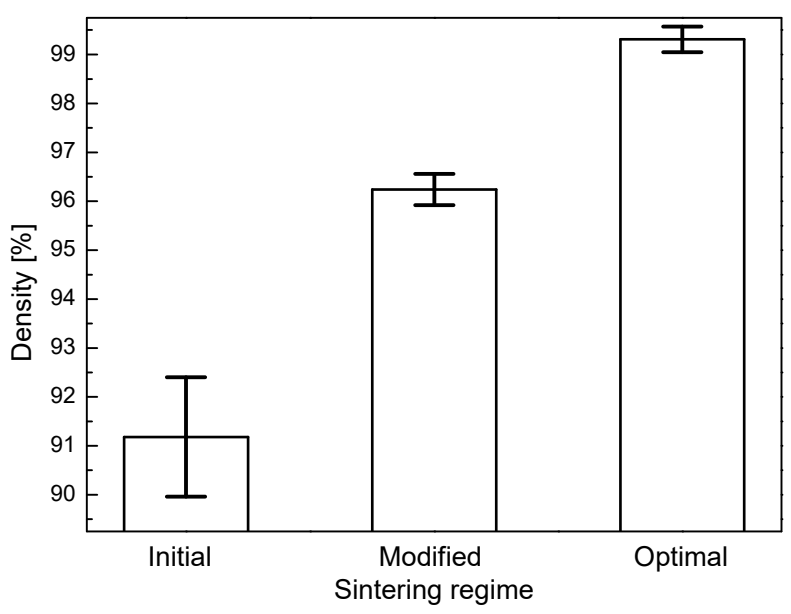

Fig. 6 Comparison of densities at different sintering regimes

\section{Microstructure of $\mathrm{B}_{4} \mathrm{C}-\mathrm{TiB}_{2}$ ceramic composites}

The microstructures of $\mathrm{B}_{4} \mathrm{C}$ based ceramic composites hot pressed at the same final sintering temperature of $1850{ }^{\circ} \mathrm{C}$, the same sintering time of $60 \mathrm{~min}$, and the same pressure of $35 \mathrm{MPa}$, but at applying of different sintering regimes are documented in fig. 7 (modified sintering regime) and 8 (optimal sintering regime). The microstructures of both presented samples consist of two phases which identification was 
confirmed by XRD analysis. Dark areas in both micrographs represent boron carbide $\left(\mathrm{B}_{4} \mathrm{C}\right)$ phases and light areas represent titanium diboride $\left(\mathrm{TiB}_{2}\right)$ phases. Without these phases, the sample in fig. 7 , prepared using modified sintering regime, and with the average density of $96.24 \%$ shows relatively large portion of rest porosity. Because of relatively low relative density values of hot pressed $\mathrm{B}_{4} \mathrm{C}-\mathrm{TiB}_{2}$ ceramic composite depicted in fig. 7 , mechanical properties of the composite were not measured.

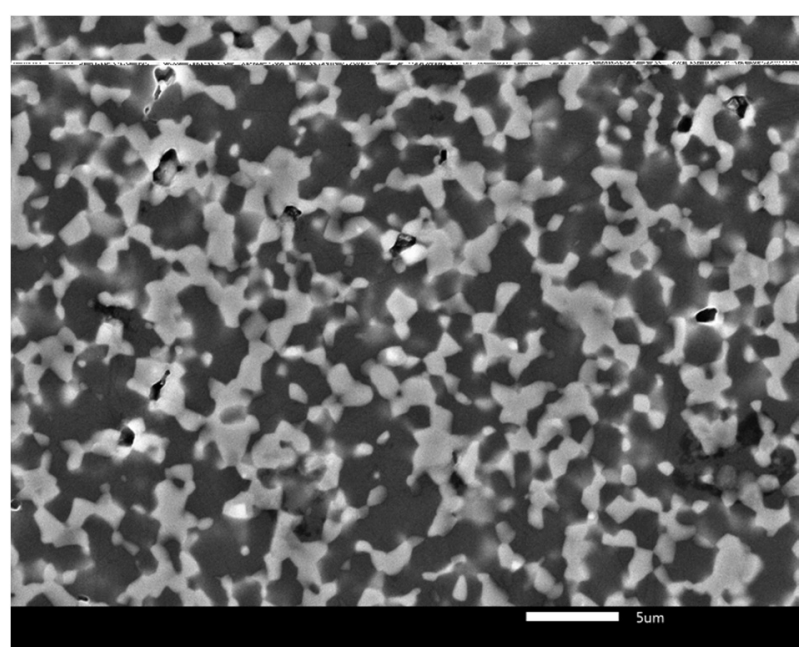

Fig. 7 Microstructure of $\mathrm{B}_{4} C-\mathrm{Ti} \mathrm{B}_{2}$ ceramic composite hot pressed using modified sintering regime

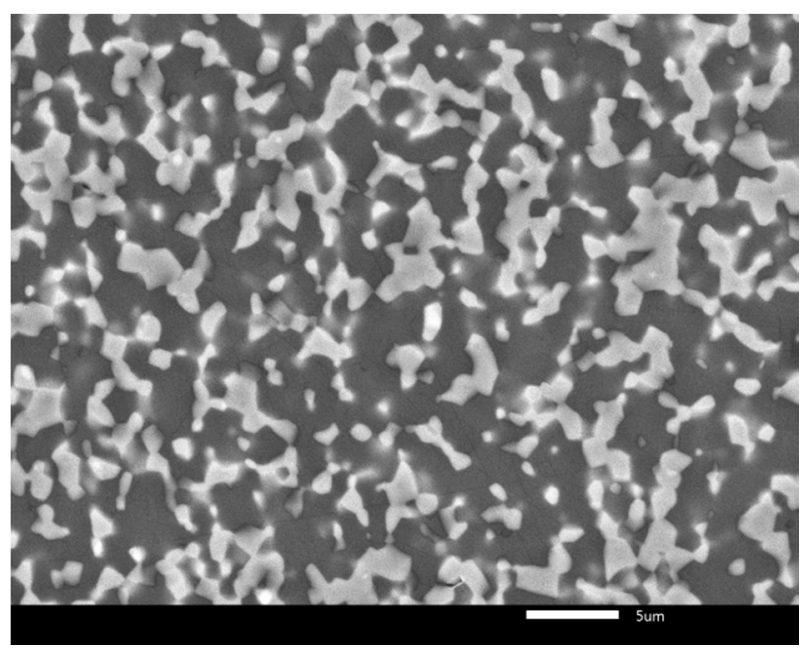

Fig. 8 Microstructure of $B_{4} C-T i B_{2}$ ceramic composite hot pressed using optimal sintering regime

Applying of the optimal sintering regime during hot pressing process of $\mathrm{B}_{4} \mathrm{C}-\mathrm{TiB}_{2}$ ceramic composites enabled to prepare ceramic composite samples with the average density of $99.31 \%$. The microstructure of this $\mathrm{B}_{4} \mathrm{C}-\mathrm{TiB}_{2}$ ceramic composite without visible rest porosity is depicted in fig. 8 . The portions of in situ created phases in fig. 8 were measured using the image analysis. According the image analyse the microstructure of ceramic composite in fig. 8 consists of 70.5 vol. $\% \mathrm{~B}_{4} \mathrm{C}$ matrix reinforced with 29.5 vol. $\% \mathrm{TiB}_{2}$ sec- ondary phase. Fully dense microstructure was the consequence of advanced mechanical properties and the $\mathrm{B}_{4} \mathrm{C}-\mathrm{TiB}_{2}$ ceramic composite reached the average hardness value of $29.8 \mathrm{GPa}$ and the average fracture toughness of $6.9 \mathrm{MPa} \cdot \mathrm{m}^{1 / 2}$. These values can be compared with the results in works $[2,4,8,10,11]$, where similar mechanical properties were measured.

\section{Conclusions}

Boron carbide based ceramic composite materials were hot pressed utilising in situ reaction of $\mathrm{B}_{4} \mathrm{C}$ powder with $40 \mathrm{wt} . \%$ of $\mathrm{TiO}_{2}$ sintering additive. The in situ reaction during hot pressing of $\mathrm{B}_{4} \mathrm{C}$ and $\mathrm{TiO}_{2}$ initial powder mixture resulted in creation of ceramic composite composed of $\mathrm{B}_{4} \mathrm{C}$ matrix reinforced with $\mathrm{TiB}_{2}$ secondary phase. In situ sintering of the composite was accompanied with evolution of volatile species, which must be properly removed during hot pressing process.

Based on the measurement of vacuum level during hot pressing process intensive volatile species were produced in the temperature interval from 1500 to $1850^{\circ} \mathrm{C}$. Creation of volatile species by in situ reaction caused large problems during hot pressing process. Cracks on the sample surfaces and significant porosity were observed at applying of pressure in sintering temperature interval from 1500 to $1570{ }^{\circ} \mathrm{C}$. The porosity acted as canals for removing of volatile species.

Prolongated dwell of $60 \mathrm{~min}$ at temperature of $1570{ }^{\circ} \mathrm{C}$ decreased cracks amount on the surfaces of samples, but the densification of samples was insufficient. The samples reached the density value of 96.24 $\pm 0.32 \%$. The porosity in the centres of samples was caused by premature densification of surface areas of samples, before the volatile species could be removed from the bulk volume.

The optimal sintering regime enabled to prepare fully dense $\mathrm{B}_{4} \mathrm{C}-\mathrm{TiB}_{2}$ ceramic composite materials. Firstly, the precursors were heated to the sintering temperature of $1850^{\circ} \mathrm{C}$, and secondly, pressure of 35 $\mathrm{MPa}$ was progressively applied. This sequence was necessary for achieving of ceramic composite compacts without any surface defects. The ceramic composite hot pressed at optimal sintering regime were composed of $\mathrm{B}_{4} \mathrm{C}$ matrix with $29.5 \mathrm{vol} . \% \mathrm{TiB}_{2}$ secondary phase. The composites reached the density of $99.31 \pm 0.26 \%$, average hardness value of $29.8 \mathrm{GPa}$, and fracture toughness of $6.9 \mathrm{MPa} \cdot \mathrm{m}^{1 / 2}$.

\section{Acknowledgements}

This work was supported by the Scientific Grant Agency of the Ministry of Education, Science, Research and Sport of the Slovak Republic under the VEGA 1/0298/18 contract. The work was supported by UVP STU Bratislava the ITMS 26240220084 project. 


\section{References}

[1] HU, J., ZHANG, F., WANG, W., FU, Z., ZHANG, J. (2019). Effect of impurities introduced by ball milling on hot pressed boron carbide. Journal of the European Ceramic Society, vol. 39, Elsevier, Amsterdam, pp. 2874 - 2881.

[2] SIVKOV, A., RAKHMATULLIN, I., SHANENKOV, I., SHANENKOV, Y. (2019). Boron carbide $\mathrm{B}_{4} \mathrm{C}$ ceramics with enhanced physico-mechanical properties sintered from multimodal powder of plasma dynamic synthesis. International Journal of Refractory Metals \& Hard Metals, vol. 78, Elsevier, Amsterdam, pp. $85-91$.

[3] PRAMANICK, A., DEY, P.P., DAS, P.K. (2020). Microstructure, phase and electrical conductivity analyses of spark plasma sintered boron carbide machined with WEDM. Ceramics International, vol. 46, Elsevier, Amsterdam, pp. $2887-2894$.

[4] HEYDARI, M.S., BAHARVANDI, H.R. (2015). Comparing the effects of different sintering methods for ceramics on the physical and mechanical properties of $\mathrm{B}_{4} \mathrm{C}-\mathrm{TiB}_{2}$ nanocomposites. International Journal of Refractory Metals and Hard Materials, vol. 51, Elsevier, Amsterdam, pp. $224-232$.

[5] SHOSHIN, A., BURDAKOV, A., IVANTSIVSKIY, M., KLIMENKO, M., POLOSATKIN, S., SEMENOV, A. (2019). Properties of boron carbide ceramics made by various methods for use in ITER. Fusion Engineering and Design, vol. 146, Elsevier, Amsterdam, pp. $2007-2010$.

[6] LU, R., CHANDRASEKARAN, S., DU FRANE, W.L., LANDINGHAM, R.L., WORSELY, M.A., KUNTZ, J.D. (2018). Complex shaped boron carbides from negative additive manufacturing. Materials and Design, vol. 148, Elsevier, Amsterdam, pp. 8 - 16.

[7] GÁBRIŠOVÁ, Z., BRUSILOVÁ, A., ŠVEC, P. (2019). Study of Sintering Parameters and Sintering Additives Effect on selected properties of Silicon Nitride. Manufacturing Technology, vol. 19, no. 2, J. E. Purkyne University in Usti nad Labem, Usti nad Labem, pp. 222 - 227.

[8] MORADKHAMI, A., BAHARVANDI, H. SAMANI, M.H.M. (2016). Mechanical properties and microstructure of $\mathrm{B}_{4} \mathrm{C}-\mathrm{NanoTiB}_{2}-$ $\mathrm{Fe} / \mathrm{Ni}$ composites under different sintering temperatures. Materials Science and Engineering A, vol. 665, Elsevier, Amsterdam, pp. 141 - 153.
[9] SAIRAM, K., VISHWANADH, B., SONBER, J.K., TAMMANA, S.R., MURTHY, C., MAJUMDAR, S., MAHATA, T., BASU, B. (2018). Competition between densification and microstructure development during spark plasma sintering of $\mathrm{B}_{4} \mathrm{C}-\mathrm{Eu}_{2} \mathrm{O}_{3}$, Journal of the American Ceramic Society, vol. 101, John Wiley \& Sons, New York, pp. 2516 - 2526.

[10] ZHANG, X., GAO, H., ZHANG, Z., WEN, R., WANG, G., MU, J., CHE, H., ZHANG, X. (2017). Effects of pressure on densification behaviour, microstructures and mechanical properties of boron carbide ceramics fabricated by hot pressing. Ceramics International, vol. 43, Elsevier, Amsterdam, pp. 6345 - 6352.

[11] FAILA, S., MELANDRI, C., ZOLI, L., ZUCCA, G., SCITI, D. (2018). Hard and easy sinterable $\mathrm{B}_{4} \mathrm{C}-\mathrm{TiB}_{2}$-based composites doped with WC. (2018). Journal of the European Ceramic Society, vol. 38, Elsevier, Amsterdam, pp. 3089 -3095 .

[12] GU, J., MA, P., WANG, H., ZHANG, J., WANG, W. FU, Z. (2019). Reactive sintering of $\mathrm{B}_{4} \mathrm{C}-\mathrm{TaB}_{2}$ ceramics via carbide boronizing: Reaction process, microstructure and mechanical properties. Journal of Materials Science \& Technology, vol. 35, Elsevier, Amsterdam, pp. 2840 2850.

[13] ZHANG, X., ZHANG, Z., WEN, R., WANG, G., ZHANG, X. MU, J., CHE, H., WANG, W. (2018). Comparisons of the densification, microstructure and mechanical properties of boron carbide sintered by hot pressing and spark plasma sintering. Ceramics International, vol. 44, Elsevier, Amsterdam, pp. 2615 - 2619.

[14] MOSHTAGHIOUN, B.M., LAGUNABERCERO, M.A., GOMEZ-GARCIA, D. PENA, J.I. (2019). Does grain size have an influence on intrinsic mechanical properties and conduction mechanism of near fully dense boron carbide ceramics. Journal of Alloys and Compounds, vol. 795, Elsevier, Amsterdam, pp. 408 -415 .

[15] NEUMAN, E.W., BROWN-SHAKLEE, H.J., HILMAS, G.E., FAHRENHOLTZ, W.G. (2018). Titanium diboride-silicon carbide-boron carbide ceramics with super-high hardness and strength. Joumal of the American Ceramic Society, vol. 101, John Wiley \& Sons, New York, pp. $497-501$.

[16] ZHANG, X., ZHANG, Z., NIE, B., CHEN, H., WANG, Y., ZHENG, L., BAI, Y., WANG, W. (2018). Microstructure and mechanical 
properties of fine-grained boron carbide ceramics fabricated by high-pressure hot pressing combined with high-energy ball milling. Ceramics International, vol. 44, Elsevier, Amsterdam, pp. $10766-10772$

[17] ŠVEC, P., GÁBRIŠOVÁ, Z., BRUSILOVÁ, A. (2019). Microstructure and mechanical properties of $\mathrm{B}_{4} \mathrm{C}-\mathrm{TiB}_{2}$ ceramic composites hot pressed with in-situ reaction. Journal of Ceramic Processing Research, vol. 20, no. 1, Hanyang University, Seoul, pp. $113-120$.
[18] CHEN, H., ZENG, F., Li, W., LIU, J., GU, Y., ZHANG, F. (2019). Densification behavior and mechanical properties of spark plasma reaction sintered $\mathrm{ZrB}_{2}-\mathrm{ZrC}-\mathrm{B}_{4} \mathrm{C}$ ceramics from $\mathrm{B}_{4} \mathrm{C}-\mathrm{Zr}$ system. Ceramics International, vol. 45, Elsevier, Amsterdam, pp. 12122 - 12129.

[19] SWAB, J.J., PITTARI, J.J., GAMBLE, W.R. (2019). Uniaxial tensile strength and fracture analysis of a hot-pressed boron carbide. Journal of the European Ceramic Society, vol. 39, Elsevier, Amsterdam, pp. 1965 - 1973. 